\title{
Higher education internationalisation at the crossroads: effects of the coronavirus pandemic
}

\author{
Jin Liu' ${ }^{1}$ Yuan $\mathrm{GaO}^{2,3}$ (D) \\ Received: 23 June 2021 / Accepted: 25 October 2021 / Published online: 19 January 2022 \\ (c) The European Higher Education Society 2022
}

\begin{abstract}
The COVID-19 pandemic has influenced nearly every aspect of people's lives, and has set new conditions for universities to operate their internationalisation practices. Together with the rapidly changing global environment, higher education internationalisation has reached a crossroads. Through a constructivist grounded theory design, this study explores experts' thoughts about the coronavirus crisis's influences on the internationalisation of higher education and its future direction, taking different national and regional contexts into account. Interviews with 20 world-leading scholars in the field suggested that COVID19 has had complex effects on university internationalisation and it is necessary to consider such effects beyond the simple distinction between challenges and opportunities. New approaches to conceptualise and implement internationalisation are essential, while the logic of capitalism remains powerful. When looking at the future, many factors other than the coronavirus will exert their force. New conditions have raised new requirements for internationalisation, and therefore, new knowledge is needed to maintain its relevance and sustainability.
\end{abstract}

Keywords Higher education · Internationalisation · COVID-19 - Interviews · Experts · Impacts · Future

\section{Introduction}

When COVID-19 was first detected in Wuhan and spread across China last December, no one thought it would evolve into a global health crisis. By 25 October 2020, the coronavirus had infected 42,512,186 people worldwide, with over 400,000 new registered cases

Yuan Gao

catherineyuangao@gmail.com

Jin Liu

liujinedu@bit.edu.cn

1 School of Humanities and Social Science, Beijing Institute of Technology, Beijing, China

2 Centre for International Research on Education Systems, Victoria University, Melbourne, Australia

3 Center for Higher Education Research, Southern University of Science and Technology,

Shenzhen, China 
daily. The pandemic has caused more than one million deaths (World Health Organization, 2020). Indeed, according to the UN chief, the current coronavirus outbreak has become the greatest challenge for the world since World War Two ("Coronavirus: Greatest test since World War Two, says UN chief,“ 2020). COVID-19 has left few aspects of people's lives untouched, and higher education is no exception. In March 2020, the onset of the pandemic, UNESCO (2020) estimated that approximately 1.7 billion students and 63 million educators had left their conventional education environments. The former figure accounts for $90 \%$ of the world's student population.

In the astonishing number of analyses and forecasts of COVID-19's influences on higher education, the spotlight has been on global students and academics' mobility, which is a key feature of higher education internationalisation. The pandemic has reduced both students and faculty's physical mobility significantly in the short-to-medium term. Many countries have implemented travel bans and quarantines, which has prevented international students from entering and returning, and forced them to either defer their study or rely on distance learning from home. In addition to mobility, other key dimensions of higher education internationalisation have also been affected considerably, while not necessarily adversely. As most university's functions have transferred to the digital space, it creates opportunities for academics from different countries to deliver talks, lectures, and seminars online, which is a less costly and more approachable way to internationalise the curriculum and allow it to reach a wider audience (Gu \& Teng, 2020).

Even before COVID-19, many uncertainties were clouding the prospects of higher education internationalisation, including growing geopolitical tensions, the rise of nationalism and populism, bans on immigration, anti-globalisation protests, and anti-integration trends (e.g., Brexit). The pandemic has accelerated these changes, amplified the pre-existing challenges, added new difficulties, as well as offered opportunities (de Wit \& Altbach, 2020; Gu \& Teng, 2020; Hudzik, 2020; Wang, 2020). Hence, higher education's internationalisation has come to a crossroads, and during this critical time, it is meaningful and important to think about its future and consider the health crisis's effects. The majority of the research available on COVID-19's influences on higher education internationalisation has been conducted in the form of self-reflection or theoretical discussions and projections. The limited number of empirical studies has focused on a single national or regional context (e.g., see Finardi \& Guimaraes, 2020; Peters et al., 2020). Hence, this study was designed to fill the gap in the literature by interviewing leading international scholars in the field to discuss the possible changes that the pandemic may cause in both the conceptualisation and practice of internationalisation in the global higher education field and offer insights to policymakers, practitioners, and researchers.

\section{Managing internationalisation in an abnormal environment}

International education has shifted largely to a virtual environment because of the coronavirus pandemic. Although distance learning offers only partial experiences that students yearn for in international education, it at least allows universities to continue to deliver most courses and programs to international students. The advantages of online learning not only make it a valuable complement to traditional models of international or intercultural education, but also create new opportunities for wider participation in internationalisation actions and dialogues. As Finardi and Guimaraes (2020) argued, the sudden shift to online international learning as a result of the crisis has allowed many universities in the Global 
South that were unable to participate in internationalisation previously because of the high cost involved in academic mobility and international travel to join international conversations through virtual exchanges.

However, these advantages may not lead to a permanent transformation from the traditional to virtual model of internationalisation practice in a post-pandemic climate. On the one hand, international students have expressed dissatisfaction with remote learning. This highlights the intrinsic value of "experiencing" another academic system and particularly, a culture physically, and indicates that the power of meeting someone face-to-face should not be underestimated, even when people can remain connected digitally (Marginson, 2020). On the other hand, the higher education community has yet to be prepared fully to implement internationalisation in the digital space and there are two significant gaps to address: The infrastructure and pedagogy (Amemado, 2020; Stallivieri, 2020).

In addition to distance learning, the government and universities in different countries have taken other active measures to support international students. For example, as a result of COVID-19, the Canadian government has adjusted work regulations for international students to allow them to continue their work in the case that they become part-time students, or take breaks in their studies. The restriction to a maximum 20-hour work week for international students has also been suspended when the job is in a COVID-19-essential service or function (El Masri \& Sabzalieva, 2020). Similarly, Australian universities have worked hard with the federal and state governments to reduce the disruption in international students' study and lives the pandemic has caused. Common responsive measures include providing discounted tuition fees for students taking online classes, delaying the start date of the semester, refunding fees and deferring payment, and setting up special helplines (Leask \& Ziguras, 2020; Marinoni \& van't Land, 2020).

Although internationalisation is a global phenomenon that affects higher education institutions (HEIs) in nearly all nations in the world, the importance of international education to the financial stability of a nation's higher education sector varies from country to country. Undoubtably, the coronavirus pandemic has had the greatest adverse effects on those countries that rely heavily on incoming students as income generators. Universities in the UK and Australia have embraced internationalisation in a commercial approach since the 1980 s, followed by other English-speaking countries, such as Canada and New Zealand, and several continental European nations more recently (de Wit \& Altbach, 2020). This market approach reflects the underlying logic of capitalism, and emphasises recruiting international students to generate income (Brown, 2015; Rizvi, 2020). Thus, the stagnation in global mobility the COVID-19 crisis has caused posed a severe financial challenge to HEIs in these countries immediately (Usher, 2020), and has forced them to implement layoffs and wage cuts.

Although the physical barriers will be removed in the future with the development of a vaccine against the coronavirus, it may not be easy for universities to resume their internationalisation activities to the pre-pandemic level immediately. First, COVID-19's economic effects will persist for many years (Bothwell, 2020). In June 2020, McKinsey \& Company (2020a) reported survey findings that indicate that more than 90 per cent of respondents in every global region projected declining economic conditions-except in China, where fewer than half of the respondents held a pessimistic view. In a following report, they predicted a "slow and muted" global recovery that will last several years (McKinsey \& Company, 2020b). As massive expenditures will target stabilising economies during the crisis and their recovery thereafter, it is expected that future public allocations to higher education will shrink, and in particular, universities will have fewer resources to mobilise for internationalisation (Yang, 2020). 
The economic recession the COVID-19 crisis has caused will also influence the affordability of studying overseas. Much of the global student mobility has been driven by the emergence of a middle class, which is likely to be affected most by economic conditions (Marginson, 2020). Although the pandemic has not altered this group's motivation to send their children to study abroad, an economically pessimistic outlook and fear of vulnerability may encourage they to consider both monetary expenditures and behavioural choices more seriously (Yang, 2020). Further, given that health and safety are key factors that influence parents and students' decision to study overseas, emotions such as the fear the global health crisis has induced could affect the demand for international education in the future (Gu \& Teng, 2020).

Second, the degree of trust and coordination between the federal government, state/provincial government, and individual HEIs in responding to, and managing the effects of, the crisis on higher education internationalisation will determine the speed and scope of the recovery powerfully. It has been observed that many actions taken to support international education during the pandemic in some Western countries, such as Canada and Australia, were largely dispersed and uncoordinated (El Masri \& Sabzalieva, 2020), while in China and Japan, measures were implemented in a more organised manner (e.g., see Marginson, 2020; Peters et al., 2020).

Although neither the pandemic's scope and outcomes nor its implications for higher education are clear, many scholars have advocated critical reflection on the current dominant commercial approach to internationalisation (de Wit, 2020; Finardi \& Guimaraes, 2020; Rizvi, 2020; Yang, 2020). The coronavirus crisis has revealed starkly the vulnerability of such an approach and shows that depending on international students as income generators is deeply problematic. The pandemic serves as an opportunity to re-imagine the ways in which internationalisation could be achieved, particularly through more sustainable and reciprocal models (El Masri \& Sabzalieva, 2020; Wang, 2020).

\section{The study}

This study intended to understand higher education internationalisation in the COVID-19 pandemic, which is an ongoing process with much openness and many possibilities. Such nature of the inqury suggests a grouded theory design, highlighting a process approach, fit its purpose best. As Corbin and Strauss (2008) argued, grounded theory is widely used to generate an understanding of a process related to a substantive topic, which is a sequence of actions and interactions among people and events. This study intended to yield such understanding from experts' perspective. Accordingly, a constructivist approach was employed, of whcih methodological underpinnings focus on how participants' construct meaning in relation to the phenenomen of inquiry (Charmaz, 2014). This approach is particularly powerful in revealing views, values, beliefs, assumptions, and ideologies of individuals, and any conclusions drawn through the approach are explanatory, suggestive, incomplete, and inconclusive (Charmaz, 2014).

A constructivist design relys heavily on interviews as its data collection technique (Charmaz, 2014; Creswell, 2007). Theoretical sampling, as a unique purposeful sampling strategy, is commonly used, which indicates that the researcher intentionally chooses participants who can yield data useful in generating an explanationfor a substantive topic (Creswell, 2012). As this study regarded higher education internationalisation as a multidimensional practice that HEIs across regional and national contexts have approached in 
significantly varied ways, interviewees were selected from all six continents to contribute diverse perspectives and consider different contexts.

Unstructured interview was employed because of its unique strengths, such as providing interviewers more flexibility in the way they probe for details than in other more structured styles of interviewing, and revealing issues that the interviewer had not considered before. Further, as internationalisation can be conceptualised in various ways, unstructured interviews allow the participants to describe the key concepts in their own vocabulary and terminology (Wilson, 2013), although it must be admitted that the interview's unstructured nature poses challenges for interviewers. It normally takes longer for each individual interview compared to other types, and requires interviewers' advanced interviewing techniques (Corbin \& Morse, 2003). Considering these challenges fully, all of the interviews in this study were conducted by the same two experienced researchers, each with more than eight years of qualitative research experience in the field. Abundant time was allocated for the entire data collection process and the interviewers conducted only one interview per day to guarantee their concentration during the process and prevent exhaustion.

The two Principal Investigators (PIs) in the study identified senior scholars in the field to form an initial list of targeted participants. Sequential sampling followed to recruit appropriate interviewees from regions that were not covered in the initial list. The final sample included 20 participants, and their demographic and professional information is presented in Table 1. One limitation of the sample is that because of the availability of scholars who met the selection criteria and had the available time and resources, not all regions were

Table 1 Participants' demographic and professional information*

\begin{tabular}{|c|c|c|}
\hline Interviewee & Region & $\begin{array}{l}\text { Institutional } \\
\text { leadership } \\
\text { position }\end{array}$ \\
\hline Interviewee_E1 & Europe & Yes \\
\hline Interviewee_E2 & Europe & No \\
\hline Interviewee_E3 & Europe & Yes \\
\hline Interviewee_NA4 & North America & Yes \\
\hline Interviewee_NA5 & North America & Yes \\
\hline Interviewee_NA6 & North America & Yes \\
\hline Interviewee_O7 & Oceania & No \\
\hline Interviewee_O8 & Oceania & Yes \\
\hline Interviewee_E9 & Europe & Yes \\
\hline Interviewee_O10 & Oceania & No \\
\hline Interviewee_EA11 & East Asia & Yes \\
\hline Interviewee_EA12 & East Asia & Yes \\
\hline Interviewee_SEA13 & Southeast Asia & Yes \\
\hline Interviewee_SA14 & South Asia & No \\
\hline Interviewee_A15 & Africa & No \\
\hline Interviewee_SA16 & South America & No \\
\hline Interviewee_E17 & Europe & Yes \\
\hline Interviewee_EA18 & East Asia & Yes \\
\hline Interviewee_ME19 & Middle East & No \\
\hline Interviewee_ME20 & Middle East & Yes \\
\hline
\end{tabular}

*All participants are full professors 
represented equally in the sample. It is noteworthy that over half of the participants have been in leadership positions at the faculty or institutional level, which indicates that their thoughts on the pandemic and higher education internationalisation provided not only theoretical, but also policy and practical perspectives.

The targeted participants were contacted via email to invite them to participate and a plain language statement that documented the study's purpose and the three guiding questions (see Table 2) for the interview were sent with the consent form through email. All interviews were conducted online in English using ZOOM from late August to early October 2020; each interview lasted between 60 and $75 \mathrm{~min}$ and was recorded digitally and transcribed by one PI. Both PIs were present at each interview, during which one led the conversation and the other served as backup. Many probing questions were asked following the participants' initial response to each broad guiding question. The PIs performed Constructivist Grounded Theory Method Coding (Bryant, 2017; Charmaz, 2014), which consists of three steps of coding. Interview transcripts were scrutinised line-by-line in the initial open-coding, then a combined focused and theoretical coding technique was used to merge the initial codes into more aggregated codes, based on which the final overarching concept could be refined. Throughout all three steps, the two PIs cross-checked the codes for consistency and reliability.

\section{Learning through the pandemic}

The COVID-19 crisis has forced governments and universities to operate and manage internationalisation in an abnormal environment, and policymakers, researchers, and practitioners have to innovate both their understanding and practice of higher education internationalisation throughout the pandemic. As Interviewee _E1 put it, "The COVID-19 pandemic to international education is really not one of the great disasters of all time. It's a set of conditions which have changed quickly and we need to adjust, we need to learn that, and we need to grow to cope with this." This section presents the participants' thoughts and reflections on the global health crisis's influences on the evolution of internationalisation.

\section{Beyond the dichotomy of challenges and opportunities}

When asked about the pandemic's major influences on higher education internationalisation, many participants suggested that highly sophisticated thinking is required, which breaks the simple dualisms, such as optimism versus pessimism, or opportunities versus restrictions (Interviewees _E1, E17, O10, \& ME20). They agreed that the health crisis is a painful reality, and universities need to survive in this reality and find new ways of

Table 2 Guiding questions for the unstructured interview

\begin{tabular}{ll}
\hline Question \\
\hline $\begin{array}{l}\text { What do you think are the major influences of the coronavirus pandemic on higher education inter- } \\
\text { nationalisation? }\end{array}$ \\
$2 \quad$ Do you think internationalisation can continue to flourish in a digital environment? \\
$3 \quad$ What is your overall projection of the future development of higher education internationalisation? \\
\hline
\end{tabular}


connecting, regardless of how difficult that may be. People are able to work creatively with fewer resources, and with individual and collective agencies, they can achieve more than they thought possible (Interviewees_E1, E17, \& O10). Some initiatives circulated and shared in response to this difficult scenario have been witnessed already, and "We need to keep working on ourselves, and making ourselves more capable and more aware and more socially responsible. There's always hope in any situation" (Interviewee_E1).

From a practical point of view, the immediate reality that universities have to face in the pandemic is restricted mobility, which affects both the supply and demand side of international education as most interviewees indicated. As one of the participants argued, "International mobility has been on an upward trajectory since 1980 . We have not seen a kind of global decline in international mobility. It has been growing from around two to five million over that period. It has grown pretty much in line with international enrolments" (Interviewee_E9). The crisis is causing a collapse in the demand for international education because people are afraid, unable to, or cannot afford to travel anymore:

"With the pandemic triggering a massive economic downturn in most countries, the capacity to pay for overseas study is going to be temporarily reduced in two to five years. The middle class will have less money" (Interviewee_E1).

"If the rising middle class in the emerging and developing countries do not have the means anymore to study in high-income countries because of the high cost of tuition fees then they have to choose different options, either to go to local institutions or to go to neighbouring countries, which makes the cost also cheaper" (Interviewee -NA4).

Interviewee _SEA13 shared some initial results of a survey about Chinese students' willingness to study overseas in 2021, which confirmed the prediction above. Over 2,000 responses to the survey show that four-fifths do not want to travel abroad to study, and the remaining one-fifth indicated a preference for neighbouring countries/regions in such destinations as Japan, Singapore, and Taiwan rather than traditional popular nations like Australia or France. Personal safety and wellbeing were reported as the major concerns for their study plan.

"Most of the crisis we have had in the past were on the demand side, but the coronavirus has also caused a crisis on the supply side. Universities cannot offer places" (Interviewee _E9). His view was echoed by other participants, who highlighted the difficulty that universities in their countries are facing in enrolling international students. Severe quarantine requirements in some countries will clearly continue, which delay international students' entry and add to their families' costs. The legal restrictions on travel will result in an awkward situation for some countries accustomed to enrolling a large number of incoming students, as the universities would like to bring them in, but cannot (Interviewees _E1, E2, \& EA12).

The participants admitted that students' mobility will be affected for the next two to three years, and nations will suffer from the influence to various degrees because of their commitment to internationalisation and their position in the global higher education landscape (Interviewees _ SA14 \& SA16). "It is assumed that the restriction of physical mobility will affect much more the high-income countries like the US, UK, Australia and will benefit emerging destination countries like China, India, Turkey, etc.” (Interviewee _NA4). However, many participants believed that international education will continue in the longterm, because the demand for overseas study is intrinsic and complex (Interviewees_E1 \& NA5). In particular, Interviewee_O7 highlighted that: 
"International education is not only good for the kids if they come back or stay away, but it is also good to cover for unpredictability for contingency. That flexible citizenship is really quite helpful to actually prepare them for whichever option becomes appropriate. Parents are making all kinds of calculations and perceiving that international education provides their kids with a strategic option. The undergraduate education in some Asian countries is as good as it is in popular Western countries, yet parents are still sending kids oversea. These are what we are imagining the world to be like because we are not planning for tomorrow but planning for 5, 10, 15 years down. In other words, we have been pushed into prediction because prediction is always helpful in controlling our situation. That is why the notion of imaginary is important because these are not realities, these are perceptions.

\section{Can internationalisation continue to flourish in the digital space?}

Internationalisation's primary feature during the pandemic is its heavy dependence on ICT to operate international education, research, and collaboration in a virtual environment. Therefore, it is natural to question whether internationalisation can continue to flourish in such an environment. While the answer to this question is complex, subtle, and controversial, according to the interviewees, internationalisation is definitely more than international mobility, but includes other endeavours to "...disseminate global knowledge and common features in the so-called world society" (Interviewee _17). Although the participants expressed mixed attitudes toward the online mode of internationalisation, some consensus has been achieved that distance learning will be used increasingly in internationalisation practice and play a more important role, yet will never substitute fully for the on-campus experience.

As early as the late $1990 \mathrm{~s}$, the internet began to play a role in providing education; however, online learning has long been a second choice compared to the face-to-face mode. The pandemic has served as a stimulus for some universities in some countries, which preferred to deliver education in the traditional way, but now have begun to embrace new technology and more internationalisation:

"In Brazil, for instance, many public universities had a lot of restrictions regarding using distance education. There was a lot of resistance inside the public universities, but now I see that we have a move forward. I have now brought my colleagues from Portugal and Finland to talk to my students in the classroom via Zoom, which I had never done before" (Interviewee_SA16).

"The virus actually has created an opportunity for the smaller institutions in particular [in Israel]. I think the big change could be the entry of smaller institutions into the game. The smaller universities can probably enjoy more opportunities to internationalise their curriculum, providing some online experience for their students to experience internationalisation, which lacked the resources to do that in the physical space" (Interviewee_ME19).

"This COVID situation has opened a lot of opportunities to many [of] those who were not covered under internationalisation. Talking from the Indian context, it is only self-supporting students have been able to go abroad. The emergence and growth of these digital platforms allows not only the creamy layer but the second level of educational institutions to provide students with some foreign experiences. This kind of partnership would be able to cover more number of students and faculty 
under the internationalisation process, which means a big change in the context of countries like India” (Interviewee_SA14).

Even faculty in developed countries appreciate the virtual environment, as it allows them to bring in leading experts around the world to work together and deliver lectures, seminar, and webinars to students and establish a learning community online for communication and discussion (Interviewees _NA4 \& O8).

While enthusiastic about the possibilities that online learning and collaboration could create, scholars were sober about these opportunities' limitations. Obstacles such as the different time zones (Interviewee _O8), the inequality in accessing digital resources (Interviewees _A15, SA14, \& ME20), and the lack of infrastructure and digital literacy (Interviewees _ NA4 \& ME19) prevent the online mode from exerting its full advantages. More importantly, operating internationalisation in a fully virtual environment has encouraged researchers to reflect further on the distinction between online and face-to-face learning, realising that they are not equivalent, although the boundaries between them have become increasingly blurred. Nearly all of the participants agreed that physical mobility will continue to be an extremely important element in internationalisation because virtual mobility fails to offer a full international experience, as illustrated by the following excerpts:

"I suppose there is a big question mark about whether international students would find what they are being offered an attractive experience. Some really genuinely do want to immerse themselves in another culture and probably have that at the back of their mind' (Interviewee_E2).

"So, people at this age when they finished their high school they want to travel, to experience, to meet new people, and to be excited. I think that these things are not going to change. I think that this is the area where internationalisation has been most successful" (Interviewee _ ME19).

"[The] physical classroom is much richer than the online one in terms of interaction and the capacity to develop combined and individual thinking through the relational setting where lots of nonverbal cues present. Online international education is not the emotion of the foreign country with a foreign language. It is not living or working there. It is not building proper relationships in the classroom of the face-to-face kind" (Interviewee_E1).

\section{Calling for new orientations}

Clearly, COVID-19 has provided the opportunity to reflect on internationalisation's nature and direction, and has exposed the vulnerability of the transactional model of international higher education and the dependence on international student fees to sustain it. In the face of the crisis, it is timely to rethink in what way the vulnerability and risk of the current approach to internationalisation could be overcome and consider the future trajectory for sustainable internationalisation practice (Interviewees _NA5 \& O10). Universities in some countries have been disabused of their assumption that they can rely on the increase in incoming students. Thus, they can no longer predict whether the students will return or not, and their understanding of the risks is now institutionalised. They realise now that they cannot actually be addicted to that source of income (Interviewee_O7).

Internationalisation's current mobility-dominant approach created opportunities only for a small elite minority of students who can afford to travel and study abroad 
(Interviewees _ NA5 \& O8). This is not sufficient. Many participants advocated that it is the critical time to bring the knowledge and cultural dimensions of internationalisation to centre stage:

"I think what will be very much increased by this current crisis is internationalisation at home. Just before COVID-19 that is beginning to be a really key aspect of internationalisation, to give as many people as possible on campus some orientation to internationalisation and some perspective on what is happening in the rest of the world and some consciousness of being global citizens" (Interviewee _NA5).

"Internationalisation should have to pay much more attention to the curriculum, integrating much more intercultural competencies elements and so on. It has also to prepare the faculty to do that. It will increase the possibilities to develop a much more international education at home policy with use of technology" (Interviewee_NA4).

"We like physical mobility of students because they learn much more than that in class. We call this experiential learning. But many other elements are not necessarily depending on physical mobility. For example, we could talk about the knowledge dimension. There are many debates nowadays on the term internationalisation of the curriculum. We should internationalise the substance of knowledge, of teaching and learning, and of research" (Interviewee_E3).

"I would hope for the future of internationalisation to be a process that revives understanding of deep-rooted spiritual and cultural traditions in different civilisations and encourages dialogue rather than conflict coming out of this. I think there is a lot of awareness with COVID-19 that science is very important for dealing with the virus and how to manage it. But there are also the deeper issues around our spiritual communication and understanding and it raises the opportunity for us to really think about those things and learn from those things" (Interviewee_EA11).

"The society needs respect among cultures. It is a totally different set of requirements for a global knowledge society related to the public good. The creation of such a society requires to bring your scholarship, your knowledge, and so on to the world in a very specific way. It needs to make a different model than the past one which economics dominated everything. The new model asks for real respect and courage and that is not easy" (Interviewee_NA6).

Although the participants argued for new directions and approaches to internationalisation, they were aware that the logic of capitalism remains powerful and the risk of resuming relying on it. There is no choice but to reflect on our current practice of internationalisation; however, the great danger is that we reflect and then resume the old mode of thinking that existed before, the commercial mode. Thus, reflection is not the problem, but acting on the reflection. There has been sufficient reflection at various conferences and on the part of various policymaking bodies and such reflection is ongoing. Universities are talking about recovery; however, the logic of the discourse of recovery itself is very limited. Much of the effort has been invested in discussing ways to recover the international student numbers rather than the way something different can be achieved (Interviewee O7). In particular, as Interviewee _O8 suggested, "The sooner we find a vaccine for the virus, the greater danger that we will just flip back to what we were doing before and less likely to think internationalisation in an innovative way. This is like sitting in a comfortable chair. So, in some ways the danger is that we will just go back to those old ways and forget what was wrong with those." 


\section{Looking at the prospects ahead}

Academics have suggested that as the pandemic's scope and outcomes remain unclear, it is too early to predict its broader implications for higher education internationalisation (de Wit \& Altbach, 2020; Yang, 2020). The participants in this study agreed with this view and emphasised that the dust has not settled yet and the assumption is that this disease is going to persist for quite a long time before we really see what the new normal is. The fluid situation globally, and the many uncertainties make it difficult to make a direct and precise projection of internationalisation's future (Interviewees _E2, NA5, SA14, A15, \& ME19), while some clues may have emerged. The interviewees shared their outlook for the future, from which it could be noted that the prospect of internationalisation is very context sensitive, in that it depends on the university and the country's current position in the global higher education field and the dominant approach that they have adopted to internationalisation.

Several participants suggested that despite some disruption in international mobility, the actual process of globalisation as a cultural and communicative form of integration at the global level is certainly continuing during the pandemic. The financial, cultural, educational, and diplomatic incentives for internationalisation continue to exist on both the demand and supply side. The world is not less connected, but seems to have become more interconnected instead in the online sensation during the crisis. Universities in some countries have been forced to move forward and connect with partners in other parts of the world using ICT. Therefore, it is probable that they can become more, rather than less, internationalised compared to their status before (Interviewees _E1, SA16, EA18, \& ME19).

Other interviewees viewed the coronavirus crisis as an acceleration of existing tendencies. On the one hand, there had been rapid change already, both in the sense of markets and transnational education activities, such as franchising branch campuses, internationalising curricula, developing joint and double degree programs, and focusing more attention on intercultural competence. Therefore, the coronavirus has simply accelerated all of those processes (Interviewee_NA4). On the other hand, the global health crisis has actually intensified inequalities in embracing internationalisation. The global South or less developed countries in Southeast Asia are actually suffering from fewer resources, and the gap between them and advantaged nations in internationalisation practice could widen even more (Interviewee_SEA13).

From all of the participants' perspectives, online connection and learning seems to be an indispensable element of future internationalisation practice. It is interesting to monitor the specific role that distance learning will play in different disciplines and at different program levels. Online interaction has the potential to reconfigure the nature of student engagement and student-teacher relationships. A number of studies has shown that students from East Asian countries are more willing to interact with teachers in the context of online teaching, possibly because they find it easier to express themselves in the virtual environment (e.g., see Dunrong \& Jin, 2020; Peters et al., 2020). Building on these experiences, a longer-term reconsideration of the role of multiple forms of education will allow HEIs to offer greater flexibility in delivering courses, open access to under-represented groups of students for international and intercultural exchange, and pave the way for inter-institutional collaboration (El Masri \& Sabzalieva, 2020).

As Interviewee_O7 emphasised, the extent to which all of this good will for the future of internationalisation can be achieved depends on innovative thinking. If the same logic that 
led to internationalisation became what it is remains being used, even in thinking about new questions, it is impossible for us to "... build a different house and to steer our practice toward multiple internationalisation from wide variety of different perspectives and locations, working with each other and trying to understand each other." In the rush to recover from the financial losses, universities may risk failing to realise the enormous potential to establish robust learning communities across national, cultural, and political differences, and reimagine the processes of knowledge ownership, creation, distribution, and use (Rizvi, 2020).

In addition to the coronavirus crisis, there are many other factors that influence the future of internationalisation, most of which lie outside the higher education sector. As indicated in the literature, many such factors had exerted their forces on the development of international education and collaboration before COVID-19, including the most significant ones, such as changing geopolitics (e.g., see de Wit \& Altbach, 2020; Gu \& Teng, 2020; Hudzik, 2020; Marginson, 2020), climate change (e.g., see Bourn, 2011; Brandenburg, et al., 2019; Smith, et al., 2019), and increasing institutional bureaucracy (e.g., see Wang, 2020). The participants in this study recognised and highlighted these factors in the interviews as well.

Most participants reported that the intensified geopolitical tensions are a worrying factor that affects the project of internationalisation. Political conflicts between nations have deep historical roots and have never faded from human society, but simply undergone ups and downs. The suspicions that had been well and truly contained in the past decades have erupted again and become much more explicit now. There are already many indications that the toxicity of the global order will be a major hurdle for international collaboration in education and research, including the worsening relations between the US and China (Interviewees _E2, E3, NA5, \& O7). Another geopolitical element is the rise of nationalism and xenophobia, a message conveyed by Brexit and other movements alike. The collapse in the kind of collective action at the global level and the nationalistic direction of institutional policies have been important trends that resist internationalisation in many ways at the governmental level (Interviewees_E2, NA5, \& SEA13).

Internationalisation in higher education has been called to make a meaningful contribution to society and to address local and global social issues-including those emphasised in the Sustainable Development Goals of the United Nations (Brandenburg, et al., 2019). Growing concern about global warming and climate change has motivated people to re-think crossborder mobility by plane and invest more efforts to internationalise and "inter-culturalise" the home campus (Interviewees_E2 \& E3). Further, the extreme bureaucracy at both the governmental and institutional levels, particularly in developing countries, has been seen as an impeding factor in effective internationalisation practice (Interviewees _ A15 \& EA18). In addition, Interviewee _E9 argued that demographics have been shaping the pattern of the global higher education market powerfully. The demographics in East Asia that have truly advanced the growth in international education are turning down, as the number of university age youth is declining very rapidly there. Such countries as Malaysia, China, and Japan all have aspirations to become major hubs and attract international students. Given these factors, mobility will become more intra- than inter-regional.

\section{Closing remarks}

The rapidly changing global and national environments in which higher education internationalisation emerged and matured, together with the disruptive coronavirus crisis, have created new conditions for policymakers, practitioners, and researchers to reconceptualise 
and implement internationalisation. The pandemic has lasted for nearly a year, and many countries have even experienced a second or even a third wave of the virus. This has resulted in immeasurable losses in lives and damaged the global economy significantly. Some vast and long-lasting influences of the crisis on different aspects of human life have become more explicit and people's understanding of the virus itself, as well as its effects, have deepened. While, it remains too early to tell the complete story.

These new conditions impose new requirements for internationalisation. For many years, the internationalisation of higher education has been seen essentially as a positive development with few disadvantages. New conditions and unexpected events such as COVID-19 have forced people to increase their awareness of those disadvantages and determine possible ways to alleviate them. In the past several decades, internationalisation has made remarkable achievements, particularly in enhancing the communication and exchange of people, ideas, and information across national boundaries. The shortcomings of the current mobility-dominant and commercially-driven approach to international education, such as the diluted quality of international programs and the omission of its social and cultural responsibilities, were largely obscured by the halo effect. Such weaknesses have become more alarming under the new conditions. Therefore, acquiring updated knowledge of higher education internationalisation is critical to fulfil such requirements, in particular its cultural mission to increase awareness and understanding of one's own and others' cultures and its social mission to engage the wider community and benefit society as a whole. Change is ever present and there will be other unexpected or disruptive events that will affect the operation of higher education internationalisatio, which present both challenges and possibilities. Our knowledge of internationalisation will never be perfect, but continues to improve, and its relevance and sustainability will grant the internationalisation of higher education a future.

Acknowledgements This project would not have been possible without the generous support of 20 leading scholars in the field of higher education internationalisation from 14 countries. We would like to thank each of them sincerely for their valuable time and insightful ideas and judgement. They are the ones who maintain a sober and critical mind in the difficult time and contribute their intelligence and passion for a brighter future of higher education internationalisation.

\section{Declarations}

Disclosure statement N/A

\section{References}

Amemado, D. (2020). COVID-19: An unexpected and unusual driver to online Education. International Higher Education, 102(special issue), 12-14. Retrieved from https://www.internationalhighereducat ion.net/api-v1/article/!/action/getPdfOfArticle/articleID/2922/productID/29/filename/article-id-2922. pdf. Accessed 13 Mar 2021.

Bothwell, E. (2020). Coronavirus: global student flows to suffer 'massive hit' for years. Times Higher Education. Retrieved from https://www.timeshighereducation.com/news/coronavirus-global-student-flowssuffer-massive-hit-years. Accessed 13 Mar 20021.

Bourn, D. (2011). From internationalisation to global perspectives. Higher Education Research \& Development, 30(5), 559-571. https://doi.org/10.1080/07294360.2011.598447

Brandenburg, U., de Wit, H., Jones, E., \& Leask, B. (2019). Internationalisation in higher education for society. University World News. Retrieved from https://www.universityworldnews.com/post.php? story=20190414195843914. Accessed 13 Mar 2021.

Brown, W. (2015). Undoing the Demos Neoliberalism's Stealth Revolution. Zone Books 
Bryant, A. (2017). Grounded Theory and Grounded Theorizing: Pragmatism in Research Practice. Oxford University Press

Charmaz, K. (2014). Constructing Grounded Theory (2nd ed.). Sage

Corbin, J., \& Morse, J. M. (2003). The unstructured interactive interview: issues of reciprocity and risks when dealing with sensitive topics. Qualitative Inquiry, 9(3), 335-354. https://doi.org/10.1177/ 1077800403009003001

Corbin, J. M., \& Strauss, A. L. (2008). Basics of qualitative research: techniques and procedures for developing grounded theory (3rd ed.). Sage Publications

Coronavirus : Greatest test since World War Two, says UN chief. (2020). BBC News. Retrieved from https://www.bbc.com/news/world-52114829. Accessed 13 Mar 2021.

Creswell, J. W. (2007). Qualitative inquiry \& research design: choosing among five approaches (2nd ed.). Sage Publications

Creswell, J. W. (2012). Educational research: planning, conducting, and evaluating quantitative and qualitative research (4th ed.). Pearson

de Wit, H., \& Altbach, P. G. (2020). Internationalization in higher education: global trends and recommendations for its future. Policy Reviews in Higher Education, 1-19. https://doi.org/10.1080/23322 969.2020.1820898

Dunrong, B., \& Jin, L. (2020). Temporary action or new model experiment? Teaching at Chinese Universities in the Time of COVID-19 International Higher Education, 102(special issue), 18-20. Retrieved from https://www.internationalhighereducation.net/api-v1/article/!/action/getPdfOfAr ticle/articleID/2922/productID/29/filename/article-id-2922.pdf. Accessed 13 Mar 2021.

El Masri, A., \& Sabzalieva, E. (2020). Dealing with disruption, rethinking recovery: Policy responses to the COVID-19 pandemic in higher education. Policy Design and Practice, 1-22. https://doi.org/10. $1080 / 25741292.2020 .1813359$

Finardi, K. R., \& Guimaraes, F. F. (2020). Internationalization and the Covid-19 Pandemic: Challenges and Opportunities for the Global South. Journal of Education, Teaching and Social Studies, 2(4), 1-15. https://doi.org/10.22158/jetss.v2n4p1

Gu, M., \& Teng, J. (2020). 后疫情时代教育国际交流与合作的 新挑战与新机遇 [New challenges and oppertunities for international exhange and cooperation in education in the post-pademic era]. 比较 教育研究 [International and Comparative Education], 9, 3-7

Hudzik, J. K. (2020). Post-COVID Higher Education Internationalization. Retrieved from https://www. nafsa.org/professional-resources/research-and-trends/post-covid-higher-education-internationaliz ation. Accessed 13 Mar 2021.

Leask, B., \& Ziguras, C. (2020). The Impact of COVID-19 on Australian Higher Education International Higher Education, 102(special issue), 36-37. Retrieved from https://www.internationalhi ghereducation.net/api-v1/article/!/action/getPdfOfArticle/articleID/2922/productID/29/filename/ article-id-2922.pdf. Accessed 13 Mar 2021.

Marginson, S. (2020). The relentless price of high individualism in the pandemic. Higher Education Research \& Development, 1-4. https://doi.org/10.1080/07294360.2020.1822297

Marinoni, G., \& van't Land, H. (2020). The impact of COVID-19 on global higher education. International Higher Education, 102(special issue), 7-9. Retrieved from https://www.internationalhighere ducation.net/api-v1/article/!/action/getPdfOfArticle/articleID/2922/productID/29/filename/articleid-2922.pdf. Accessed 13 Mar 2021.

McKinsey \& Company. (2020a) Economic conditions snapshot, June 2020: McKinsey Global Survey Results. Retrieved from https://www.mckinsey.com/business-functions/strategy-and-corporatefinance/our-insights/economic-conditions-snapshot-june-2020-mckinsey-global-survey-results\#. Accessed 13 Mar 2021.

McKinsey \& Company. (2020b) Global Economies Intelligence Executive Summary, July 2020. Retrieved from https://www.mckinsey.com/ /media/McKinsey/Business\%20Functions/Strategy\% 20 and $\% 20$ Corporate $\% 20$ Finance/Our\%20Insights/Global\%20Economics\%20Intelligence\%20exe cutive\%20summary\%20July\%202020/Global-Economics-Intelligence-executive-summary-July2020-vF.pdf. Accessed 13 Mar 2021.

Peters, M. A., Wang, H., Ogunniran, M. O., Huang, Y., Green, B., Chunga, J. O., \& Mou, C. (2020). China's internationalized higher education during Covid-19: collective student autoethnography. Postdigital Science and Education. https://doi.org/10.1007/s42438-020-00128-1

Rizvi, F. (2020). Reimagining recovery for a more robust internationalization. Higher Education Research \& Development, 1-4. https://doi.org/10.1080/07294360.2020.1823325

Smith, D. C., Banet, C., \& Martinez Romera, B. (2019). Teaching the law of energy transition in the era of internationalisation and digitalisation of legal university education: the Transatlantic University 
Collaboration in Climate Change and Energy Law (TUCCCEL) programme. Journal of Energy \& Natural Resources Law, 37(4), 443-464. https://doi.org/10.1080/02646811.2019.1663048

Stallivieri, L. (2020). International virtual education needs greater support. University World News. Retrieved from https://www.universityworldnews.com/post.php?story=20200518150642841. Accessed 13 Mar 2021.

UNESCO. (2020). Teacher Task Force calls to support 63 million teachers touched by the COVID-19 crisis. Retrieved from https://en.unesco.org/news/teacher-task-force-calls-support-63-million-teachers-touch ed-covid-19-crisis. Accessed 13 Mar 2021.

Usher, A. (2020). CORONAVIRUS (10) - STUDENT SUPPORT. Higher Education Strategy Associates. Retrieved from https://higheredstrategy.com/coronavirus-10-student-support/. Accessed 13 Mar 2021.

Wang, Y. (2020). 后疫情时代教育国际交流与合作的 新挑战与新机遇 [On three themes of internationalization of education in the post-pandemic era in China]. 比较教育研究 [International and Comparative Education], 9, 8-12

Wilson, C. (2013). Interview techniques for UX practitioners: a user-centered design method. Gale virtual reference library

World Health Organization. (2020). WHO Coronavirus Disease (COVID-19) Dashboard. Retrieved 25 October from https://covid19.who.int/?gclid=CjwKCAiAqJn9BRB0EiwAJ1SztR2mOaWI1Zd FwZrm8_AMfScjcJ2SfedFYwgT80GrOyB3NpDNKm487hoCccoQAvD_BwE1SztR2mOaWI1ZdFwZrm8_AMfScjcJ2SfedFYwgT80GrOyB3NpDNKm487hoCccoQAvD_BwE

Yang, R. (2020). China's higher education during the COVID-19 pandemic: some preliminary observations. Higher Education Research \& Development, 1-5. https://doi.org/10.1080/07294360.2020.1824212

Publisher's note Springer Nature remains neutral with regard to jurisdictional claims in published maps and institutional affiliations. 